\title{
Distribution of flying fish species (Exocoetidae) in the waters of Ambon Island
}

\author{
Friesland Tuapetel ${ }^{1,3 *}$, Charlotha Tupan ${ }^{2}$ \\ ${ }^{1}$ Faculty of Fisheries and Marine Science, Pattimura University, Indonesia \\ ${ }^{2}$ Indonesian Ichthyological Society
}

\begin{abstract}
There are 71 species of flying fish (exocoetidae) in the world, 18 species in Indonesia, and ten species in Maluku. The southern waters of Ambon Island are potential areas for catching flying fish, but the species distribution has not been reported. This study aimed to determine the composition and distribution of flying fish species caught by gillnet in the southern Ambon Island waters. The study of flying fish species was carried out from February to June 2021. There were five dominant flying fish species distributed consistently based on their respective zones. The morphological identification revealed flying fish species which broadcast on the coast of the island respectively, namely: Cypselurus poecilopterus, Cheilopogon abei, Cheilopogon spilopterus with geographical position $3^{\circ} 73^{\prime} 07^{\prime \prime S}-3^{\circ} 92^{\prime} 01^{\prime \prime S}$ and $128^{\circ} 15^{\prime} 04^{\prime \prime E}-128^{\circ} 44^{\prime} 08^{\prime \prime E}$. The high seas were dominated by Cheilopogon furcatus dan Hirundichthys oxycephalus with position $-4^{\circ} 14^{\prime} 08^{\prime \prime} \mathrm{S}-4^{\circ} 72^{\prime} 16^{\prime \prime} \mathrm{S}$ and $128^{\circ} 28^{\prime} 05^{\prime \prime} \mathrm{E}-129^{\circ} 42^{\prime} 09^{\prime \prime} \mathrm{E}$. This information could be provided as a database for the management and sustainable use of flying fish resources to support Indonesia's National Fish Reserve or Lumbung Ikan Nasional (LIN).
\end{abstract}

\section{Introduction}

Exocoetidae in the world consists of 71 species [1, 2], 18 in Indonesia [3], and 10 in Maluku [4]. The southern waters of Ambon Island are very potential, but the information on flying fish species composition is still limited $[5,6]$. In addition, information regarding the distribution of flying fish species according to inshore, nearshore, and offshore zones has not been reported. At the same time, this information is essential for the management of pelagic fish resources and capture fisheries [7] because, in the next two or three years, The waters of Maluku will become the National Fish Reserve of Indonesia or Lumbung Ikan Nasional (LIN) with Tuna Tongkol Cakalang (TTC) as the primary export fishery commodities $[8,9]$.

Flying fish is TTC's preferred prey $[10,11]$ and is a critical component in the pelagic fishery food chain [12]. Thus, this research is considered essential and urgent as support for LIN. A comprehensive understanding of flying fish distribution as the soft source of prey for fish in the higher food chain obtained from Ambon Island waters is essential. The results of studies related to flying fish distribution have been reported in several locations

\footnotetext{
*Corresponding author: friesland.tuapetel@fpik.unpatti.ac.id.
} 
as follows: Indian Ocean [13], Caribbean Waters [14, 15], Russia [16], North Carolina [17], Eastern Indonesia [18], Fakfak [19], Flores Sea [20], Ombai Strait (21), and Seram Sea [22], but the result regarding flying fish distribution in the coastal zone (inshore), near the beach (nearshore) and far from the beach (offshore) has explicitly not reported yet. This study is critical because even though the waters of the island of Ambon have an oceanic character, they have the same water mass, except in certain seasons [23]. On the other hand, it will be instrumental in determining the fishing zone between local fishers and Pattorani to minimize conflicts over the use of flying fish resources in the future by understanding the distribution of the target species of each catch. This information could be provided the database for policies in utilizing and managing pelagic fish resources in Maluku Waters, mainly flying fish in The Ambon Island waters. Therefore, this study aimed to determine the composition of flying fish species and the dominant species and analyze the distribution of the dominant species by fishing zone.

\section{Materials and methods}

\subsection{Sampling period and site}

The study was conducted from February to June 2021, and Naku Village, located in the south of Ambon Island, was set to be a fishing base for a sampling of flying fish (Figure 1). Flying fish was sampled in the three executive zones such as inshore (0.0-2.99 miles); nearshore (3.0-9.99 miles), and offshore (10+ miles) [24].

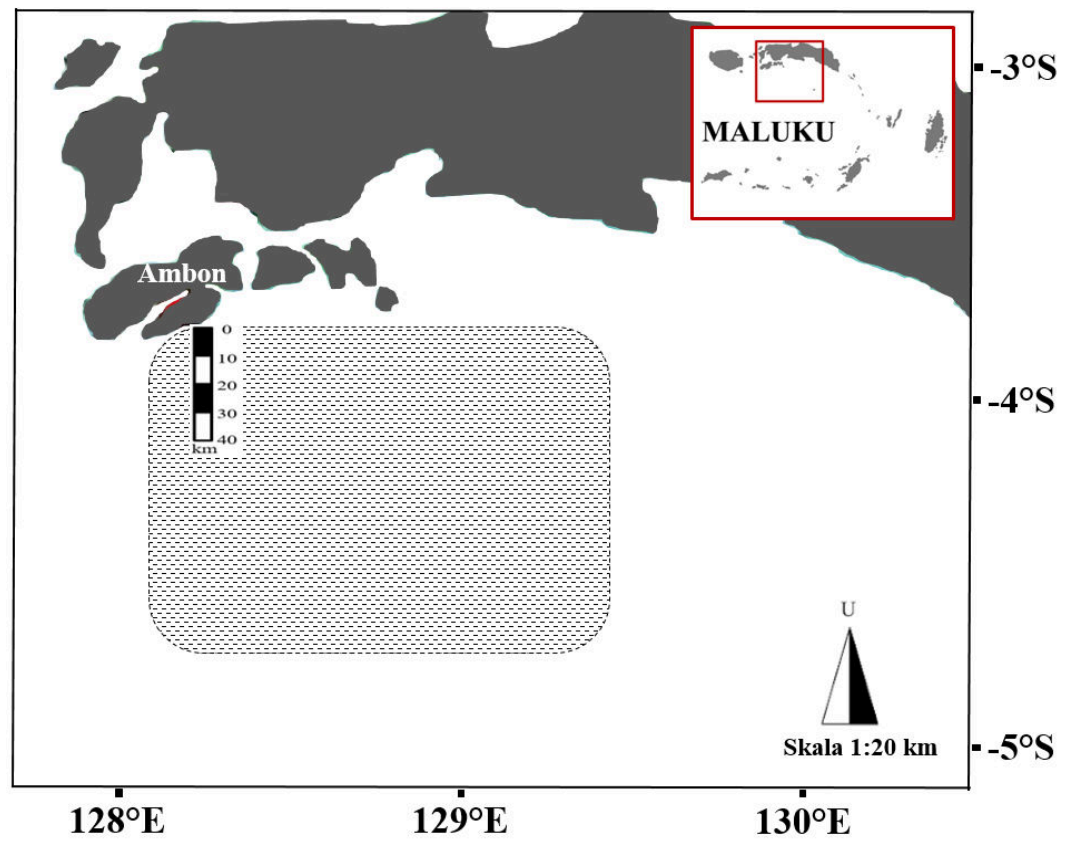

Fig. 1. Southern waters of Ambon Island. The shading of the box shows the location of flying fish sampling: Inshore (0.0-4.78 km), nearshore $(4.80-15.98 \mathrm{~km})$, and offshore $(\geq 16.00 \mathrm{~km})$ categories. 


\subsection{Sample collection}

Samples of flying fish were collected twice a month using a 1.5-inch drift gill net with a length of 200 meters and a height of 2 meters operated by local fishermen. The net was operated with a 7-meter fiber body equipped with a Yamaha Enduro E15DMH outboard motor, and GPS was used to plot the sampling points. Several equipment or materials were applied, for example, writing utensils for taking notes, a digital camera for documentation on, caliper vernier for measuring the fish, $10 \%$ formalin for preserving the samples, and the instructions [25-28] for fish identification.

\subsection{Data analysis}

The flying fish species composition was analyzed descriptively then presented in tables and figures [29]. The dominant species were analyzed morphologically [30-33], and the species distribution was analyzed using ArcGis software [34, 35].

\section{Results and Discussion}

\subsection{Species composition}

In general, four genera were found: Cheilopogon, Cypselurus, Exocoetus, and Hirundichthys, consisting of eight species. Five species were classified in the genus Cheilopogon, and three were classified in the remaining genera. Based on Table 1, the species composition caught from the most to the least respectively was Cypselurus poecilopterus (28.54\%), Cheilopogon spilopterus (21.11\%), Hirundichthys oxycephalus (20.57\%), Cheilopogon abei (14.23\%), Cheilopogon furcatus (12.22\%), Cheilopogon suttoni $(1.62 \%)$, Cheilopogon atrisignis $(0.93 \%)$, and Exocoetus volitans $(0.77 \%)$. The species distribution was detailed monthly (Table 2). The result indicated that the least amount of caught fish was in February (7.3\%), then gradually increased to the highest peak in June (34.4\%).

Table 1. Composition of flying fish species caught with gill nets in southern Ambon Island waters.

\begin{tabular}{|c|c|c|c|c|c|}
\hline No & Genus & Species & Common name & $\begin{array}{c}\text { The } \\
\text { number of } \\
\text { fish (ind.) }\end{array}$ & $\begin{array}{c}\text { Percentage } \\
(\%)\end{array}$ \\
\hline 1. & Cheilopogon & Cheilopogon abei & Abe's flyingfish & 184 & 14.23 \\
\hline 2. & Cheilopogon & Cheilopogon atrisignis & Glider flyingfish & 12 & 0.93 \\
\hline 3. & Cheilopogon & Cheilopogon furcatus & Spotfin flyingfish & 158 & 12.22 \\
\hline 4. & Cheilopogon & $\begin{array}{l}\text { Cheilopogon } \\
\text { spilopterus }\end{array}$ & $\begin{array}{l}\text { Manyspotted } \\
\text { flyingfish }\end{array}$ & 273 & 21.11 \\
\hline 5. & Cheilopogon & Cheilopogon suttoni & $\begin{array}{l}\text { Sutton's } \\
\text { flyingfish }\end{array}$ & 21 & 1.62 \\
\hline 6. & Cypselurus & $\begin{array}{l}\text { Cypselurus } \\
\text { poecilopterus }\end{array}$ & $\begin{array}{l}\text { Yellowing } \\
\text { flyingfish }\end{array}$ & 369 & 28.54 \\
\hline 7. & Exocoetus & Exocoetus volitans & $\begin{array}{l}\text { Tropical two- } \\
\text { wing flyingfish }\end{array}$ & 10 & 0.77 \\
\hline 8. & Hirundichthys & $\begin{array}{l}\text { Hirundichthys } \\
\text { oxycephalus }\end{array}$ & Bony flyingfish & 266 & 20.57 \\
\hline \multicolumn{4}{|c|}{ Total } & 1293 & 100 \\
\hline
\end{tabular}


Table 2. Distribution of flying fish species in southern Ambon Island waters for five months (February-June 2021).

\begin{tabular}{|c|c|c|c|c|c|c|c|}
\hline \multirow{2}{*}{ No } & \multirow{2}{*}{ Species } & \multicolumn{5}{|c|}{ The month year 2021} & \multirow{2}{*}{$\begin{array}{l}\text { Total fish } \\
\text { (Ind.) }\end{array}$} \\
\hline & & Feb & Mar & Apr & May & Jun & \\
\hline 1. & Cheilopogon abei & 14 & 31 & 39 & 48 & 52 & 184 \\
\hline 2. & Cheilopogon atrisignis & 1 & 1 & 4 & 0 & 6 & 12 \\
\hline 3. & Cheilopogon furcatus & 9 & 23 & 37 & 43 & 46 & 158 \\
\hline 4. & Cheilopogon spilopterus & 20 & 38 & 58 & 66 & 91 & 273 \\
\hline 5. & Cheilopogon suttoni & 0 & 0 & 2 & 8 & 11 & 21 \\
\hline 6. & Cypselurus poecilopterus & 42 & 47 & 65 & 87 & 128 & 369 \\
\hline 7. & Exocoetus volitans & 0 & 0 & 0 & 2 & 8 & 10 \\
\hline 8. & Hirundichthys oxycephalus & 8 & 26 & 54 & 75 & 103 & 266 \\
\hline \multicolumn{2}{|r|}{ Individual number of fish } & 94 & 166 & 259 & 329 & 445 & 1293 \\
\hline & Percentage (\%) & 7.3 & 12.8 & 20.0 & 25.4 & 34.4 & 100 \\
\hline
\end{tabular}

\subsection{Dominant species}

The dominant catch consisted of five species: Cheilopogon abei, Cheilopogon spilopterus, Cheilopogon furcatus, Cypselurus poecilopterus, and Hirundichthys oxycephalus, presented sequentially in Figure 2.

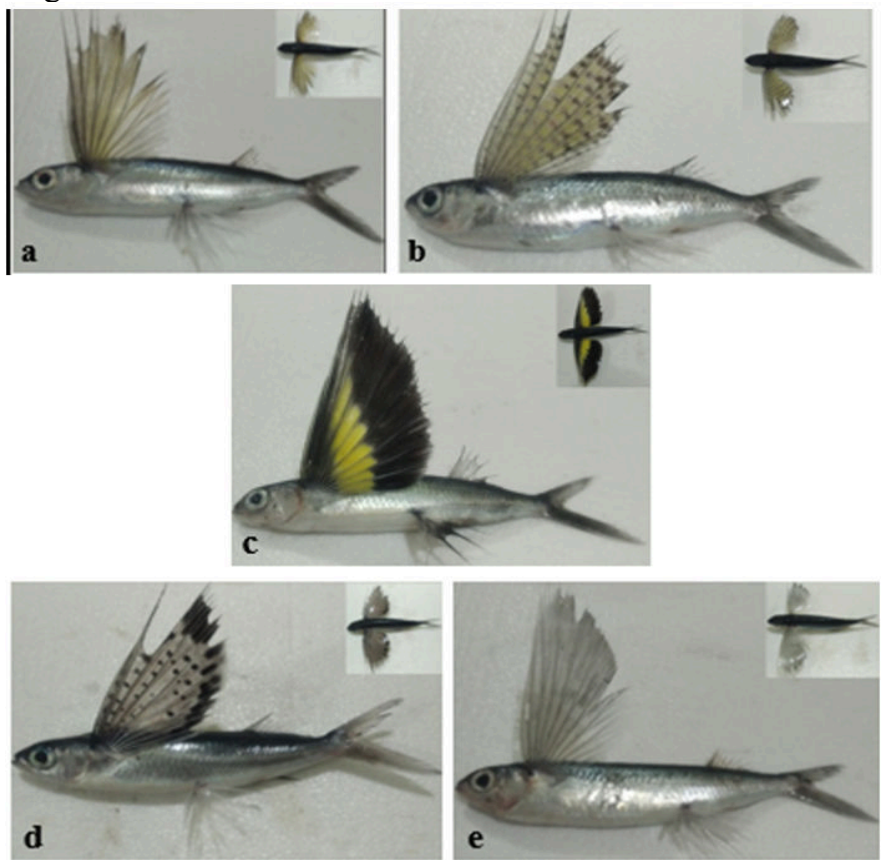

Fig. 2. The dominant flying fish species in southern Ambon Island waters were (a) Cheilopogon abei, (b) Cheilopogon spilopterus, (c) Cheilopogon furcatus, (d) Cypselurus poecilopterus, (e) Hirundichthys oxycephalus. 
The photographs of flying fish species from this study (Figure 2), show that each dominant species can be distinguished from the color pattern of the pectoral fin. Cypselurus poecilopterus has black spots, Cheilopogon abei has yellow color, Cheiolopogon spilopterus has brown spots, Cheilopogon furcatus has a black and yellow color, and Hirundichtys oxycephalus has a blue color.

Morphometrical measurement also indicated the difference among those five species (Table 3). Cypselurus poecilopterus (TL $33.2 \mathrm{~cm}$ ) appeared larger and longer in body size than the other four species. Hence, the local people called it "Antone", while the smaller one with lengths under $25.2 \mathrm{~cm}$ was called Tuing-Tuing. The body circumference of Cheilopogon furcatus $(8.9 \mathrm{~cm})$ was the smallest, while the others ranged from $9.4-11.4 \mathrm{~cm}$. The mouth opening of Hirundichtys oxycephalus $(0.9 \mathrm{~cm})$ was the smallest, while the others ranged from 1.1-1.8 cm. The distance between the dorsal fin and the tip of the head of Cheilopogon spilopterus $(11.5 \mathrm{~cm})$ was the shortest, while the others ranged from 11.9$16.2 \mathrm{~cm}$. The pelvic fin length of Cheilopogon abei $(5.0 \mathrm{~cm})$ was the longest one, while the others ranged from $3.7-4.8 \mathrm{~cm}$.

Based on Table 4, it is shown that the number of dorsal fin rays (dorsal) of Cypselurus poecilopterus was fourteen, while the other species were from eleven to twelve rays. The number of anal fin rays of Hirundichtys oxycephalus was the least (five), while the others were seven to eight. Moreover, Cheilopogon furcatus minor pectoral fin rays compared to others.

Table 3. Morphometric of dominant flying fish species in southern Ambon Island waters.

\begin{tabular}{|l|c|c|c|c|c|c|c|c|c|c|c|}
\hline \multirow{2}{*}{ Species } & \multicolumn{10}{|c|}{ Flying fish morphometric (cm) } \\
\cline { 2 - 13 } & TL & Dfl & Tfh & Pfl & Tfl & Ddh & Dfl & Pfl & Fh & Mow & Fbw \\
\hline $\begin{array}{l}\text { Cypselurus } \\
\text { poecilopterus }\end{array}$ & 33.2 & 2.0 & 6.7 & 4.8 & 6.4 & 16.2 & 4.0 & 1.6 & 3.9 & 1.8 & 11.4 \\
\hline $\begin{array}{l}\text { Cheilopogon } \\
\text { abei }\end{array}$ & 25.1 & 1.4 & 5.4 & 5.0 & 5.3 & 13.1 & 3.0 & 1.4 & 3.2 & 1.2 & 10.4 \\
\hline $\begin{array}{l}\text { Cheilopogon } \\
\text { spilopterus }\end{array}$ & 21.4 & 1.5 & 5.1 & 4.5 & 4.8 & 11.5 & 3.0 & 1.0 & 3.1 & 1.1 & 9.9 \\
\hline $\begin{array}{l}\text { Cheilopogon } \\
\text { furcatus }\end{array}$ & 22.8 & 1.9 & 5.6 & 3.7 & 4.9 & 11.9 & 3.5 & 1.5 & 2.6 & 1.1 & 8.9 \\
\hline $\begin{array}{l}\text { Hirundichthys } \\
\text { oxycephalus }\end{array}$ & 24.7 & 1.8 & 5.5 & 3.9 & 5.0 & 12.5 & 2.7 & 0.8 & 2.9 & 0.9 & 9.4 \\
\hline
\end{tabular}

Caption: TL=Total length, Dfl=Dorsal fin length, Tfh=Tail fin height, $\mathrm{Pfl}=$ Pelvic fin length, Tfl=Tail fin length, $\mathrm{Ddh}=$ Distance of the dorsal fin to the tip of the head, Dfl=Dorsal fin base length, Pfl=Pectoral fin base length, $\mathrm{Fh}=$ Fish height, Mow=Mouth opening width, $\mathrm{Fbw}=$ Fish body width.

Table 4. Meristic of dominant flying fish species in southern Ambon Island waters.

\begin{tabular}{|l|c|c|c|c|c|}
\hline \multirow{2}{*}{\multicolumn{1}{|c|}{ Species }} & \multicolumn{5}{c|}{ Number of flying fish fin rays } \\
\cline { 2 - 6 } & Dorsal & Caudal & Anal & Ventral & Pectoral \\
\hline Cypselurus poecilopterus & 14 & $10-14$ & 8 & 12 & 13 \\
\hline Cheilopogon abei & 11 & $9-12$ & 8 & 12 & 14 \\
\hline Cheilopogon spilopterus & 11 & $8-12$ & 8 & 7 & 14 \\
\hline Cheilopogon furcatus & 12 & $11-14$ & 7 & 7 & 12 \\
\hline Hirundichthys oxycephalus & 11 & $8-12$ & 5 & 7 & 14 \\
\hline
\end{tabular}




\subsection{Species Distribution}

The distribution of flying fish species in the waters of Ambon Island is presented in Figure 3 and Table 5. It is shown that the inshore zone was dominated by Cypselurus poecilopterus with a total of 326 fish or $89.07 \%$ of the total catch (366 fish). This species was mainly caught by fishermen due to the nearer fishing area with a distance less than 5 $\mathrm{km}$ from the beach, thus making it more reachable. Besides Cypselurus poecilopterus, Cheilopogon abei $6.28 \%$ and Ceilopogo spilopterus $4.64 \%$ were also found in this zone.

The nearshore zone was dominated by Cheilopogon abei $(33.82 \%)$ and Cheilopogon spilopterus $(53.78 \%)$. Cypselurus poecilopterus and Cheilopogon furcatus were also found in this zone, although in small amounts, $9 \%$ and $3 \%$, respectively.

The offshore zone was dominated by Cheilopogon furcatus (34.80\%) and Hirundichtys oxycephalus (65.20\%). Uniquely, Hirundichtys oxycephalus was only found in this zone, while Cheilopogon furcatus was also found in the nearshore zone, although only 16 individuals (3\%). The distribution of these two species was unique because the fishing area was quite distant from the coast. So it required extra time, energy, and fuel supplies from the fishermen.

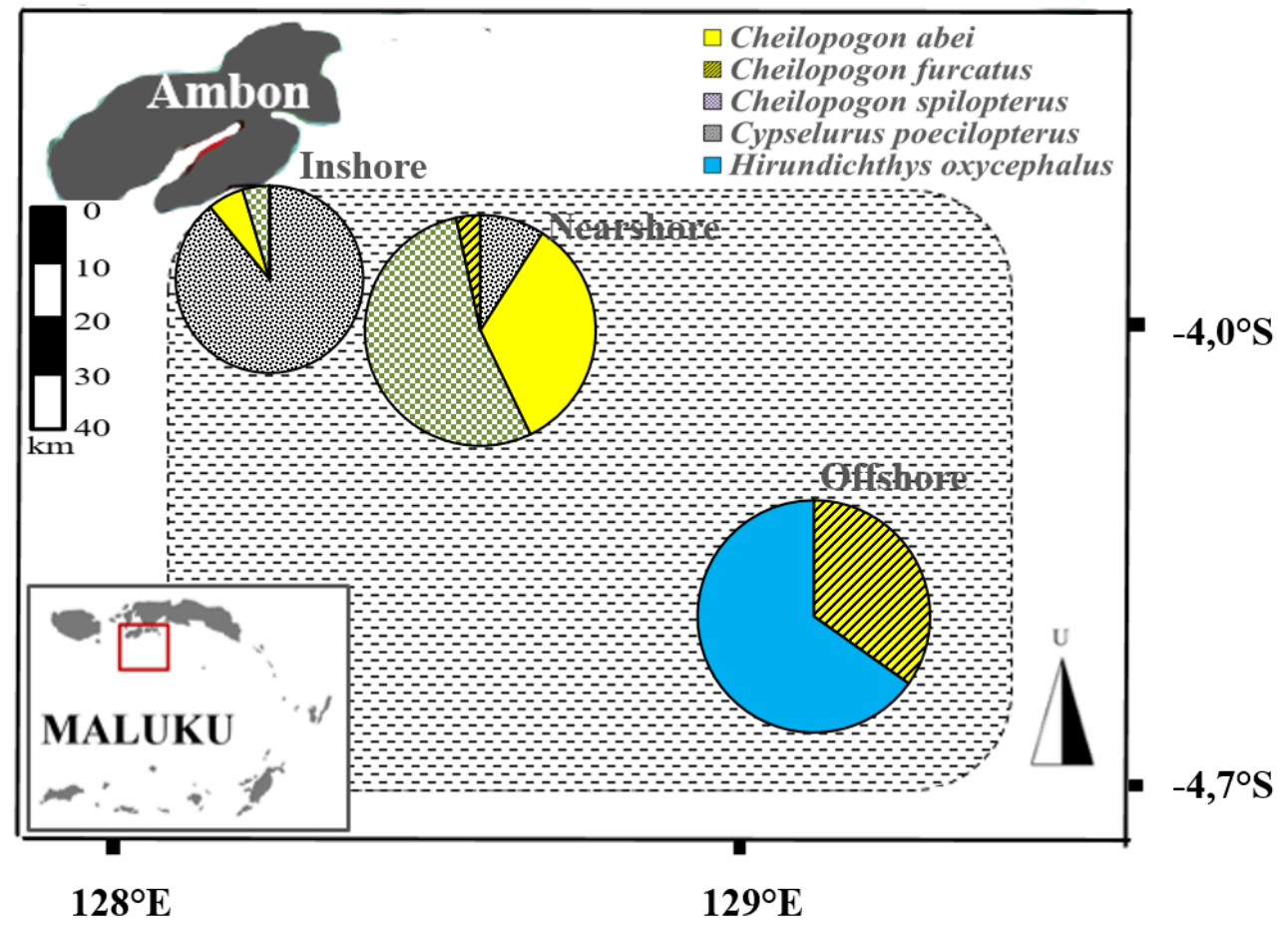

Fig. 3. Distribution of dominant flying fish species in inshore (Cypselurus poecilopterus), nearshore (Cheilopogon abei \& C. spilopterus), and offshore (C. furcatus \& H. oxycephalus). 
Table 5. Distribution of flying fish species in southern Ambon Island waters during the study period.

\begin{tabular}{|c|l|c|c|c|c|}
\hline \multirow{2}{*}{ No } & \multicolumn{2}{|c|}{ Species } & \multicolumn{2}{|c|}{ Distribution of fish in Ambon Island waters } & $\begin{array}{c}\text { The } \\
\text { number of } \\
\text { fish (Ind.) }\end{array}$ \\
\cline { 3 - 5 } & & Inshore & Nearshore & Offshore & 369 \\
\hline 1. & Cypselurus poecilopterus & 326 & 43 & 0 & 184 \\
\hline 2. & Cheilopogon abei & 23 & 161 & 0 & 273 \\
\hline 3. & Cheilopogon spilopterus & 17 & 256 & 0 & 158 \\
\hline 4. & Cheilopogon furcatus & 0 & 16 & 142 & 266 \\
\hline 5. & Hirundichthys oxycephalus & 0 & 0 & 266 & 1250 \\
\hline \multicolumn{2}{|l}{ Total fish (Individual) } & 366 & 476 & 408 & 100 \\
\hline \multicolumn{2}{|l}{ Percentage (\%) } & 29.28 & 38.08 & 32.64 & \\
\hline
\end{tabular}

The distribution of flying fish in Ambon Island waters based on dominant species (Table 5) shows that four species were found in the nearshore zone with 476 individuals or $38.08 \%$, higher than the other two zones, although the difference was insignificant. The distribution percentage of the inshore area was $29.28 \%$ with three species, and the offshore zone was $32.64 \%$ with two species. If the inshore and nearshore zones were combined then categorized as coastal zone, the number of flying fish caught dominated, namely 842 fish $(67.36 \%)$. The rest were found in the offshore zone with fewer species numbers.

\section{Discussion}

The composition of flying fish species in southern Ambon Island waters consisted of eight species and four genera, which is less than the previous report [4], namely ten species and five genera. The large number of species encountered in their study was presumably due to the length of the study period and sampling locations where the previous research was in southern Ambon Island and the northern waters of Ambon Island [5]. Furthermore, compared with the study [16], the result was nearly similar, namely eight species and five genera. The missing genus was Cyselurus, the same as reported [18]. However, compared to several studies with a small number of species such as six species and three genera [2], three species and three genera [22], two species and two genera [36], the smaller number of species and genera was presumably due to the limited study period [18], the extended location from the island (over 10 miles) [42], the differences of the fishing gear and mesh size used [6,52].

According to Figure 2, the characteristics of morphometric measurement (Table 3), and meristic counts (Table 4) of the dominant flying fish species, the morphological similarities among the species were found among Hirundichthys oxycephalus [2, 22, 32, 37, 39], Cheilopogon abei [18, 22, 38], Cypselurus poecilopterus [18, 22, 39], Cheilopogon furcatus $[18,40]$, Cheilopogon spilopterus $[1,18]$. However, differences in naming species were also identified based on morphometric characteristics: Cheilopogon abei [2, 39], Cheilopogon furcatus, and Cypselurus poecilopterus [2]. Therefore, further DNA evidence is recommended for future study $[2,4]$.

The distribution of flying fish species in Ambon Island waters was suspected to be influenced by several factors such as sea surface temperature [44, 47], changing of seasons [38, 48], food [45], and spawning [43, 46]. At the traditional market in Ambon [50], Geser [38], and Tual [49], three species were identified as similar to those species from this study (Figure 3 and Table 5). Those three species were primarily found in the inshore and nearshore zones. Following the information taken from the local fishermen, species of Cheilopogon furcatus were the most preferred prey for yellowfin tuna. It is also concluded 
by Olson et al. [41]. Besides, the dark yellow egg of Hirundicthys oxycephalus made this fish is called the original Torani [52]. Having the export-quality eggs [42] and being generally found in zones above 10 miles $[42,51]$, this species is often the main target caught by Pattorani fishermen. This information regarding flying fish distribution is beneficial to be the database for decision-makers to develop policies for sustainable utilization and management fishery, especially for these two dominant species in offshore zone. The other reason regarding the distribution's importance is that species Cheilopogon furcatus and Hirundicthys oxycephalus are the preferred prey of tuna as the primary fishery export from Maluku. Furthermore, the policymakers and fishery stakeholders need to pay more attention to the exploitation of flying fish eggs in terms of sustainable management and utilization to secure Maluku as the National Fish Reserve of Indonesia or Lumbung Ikan Nasional (LIN) [53, 54].

\section{Conclusion}

The composition of flying fish species in southern Ambon Island waters consisted of four genera and eight species but was dominated by five species consistently distributed in their respective zones. The inshore zone was dominated by Cypselurus poecilopterus, nearshore by Cheilopogon abei and Cheilopogon spilopterus, and the offshore zone by Cheilopogon furcatus and Hirundicthys oxycephalus.

\section{Acknowledgements}

Thank you to the Faculty of Fisheries and Marine Sciences, Pattimura University, for funding PNBP for superior basic research in 2021. Thank you also to Mr. Jekson, the fisherman of Naku Village, his family who have helped sample flying fish in the field, and to student Rafela Naranlele who helped identify and measure the caught fish.

\section{References}

1. R. Froese, D. Pauly. FishBase. www.fishbase.org (2021)

2. Indrayani, A.B. Sambah, A. Kurniawan, A. Pariakan, A. Jufri, D.G.R. Wiadnya, IOP Conf. Ser.: Earth and Environ. Sci. 441, 1 (2020)

3. M. Hutomo, Burhanuddin, S. Martosewojo, Flyingfish resources. (LIPI, Bogor, 1985)

4. A. Syahailatua, F. Rijoly, IOP Conf. Ser.: Earth and Environ. Sci. 789, 1 (2021)

5. A. Syahailatua, B.G. Hutubessy, F. Rijoly, H. Tuanaya, J. of Ocean 2, 1 (2009)

6. B.G. Hutubessy, A. Syahailatua, Mar. Res. in Ind. 35, 2 (2010).

7. D.D.P. Matrutty, The dynamics of fishing areas and potential fishing zones for pelagic fish in Maluku waters in Rahardjo and Tuapetel. Management and conservation of pelagic fish resources in Maluku waters National Fish Barn (Ind Ichth Soc, Cibinong, 2021)

8. F. Tuapetel, Maluku capture fisheries management to ensure the availability of national fish stocks in Latumahina. Maluku future: monog. thoughts of Maluku Academics. (Adab, Indramayu, 2021)

9. A. Haris, The potential and management of pelagic fisheries in Maluku Province in Rahardjo and Tuapetel. Management and conservation of pelagic fish resources in Maluku waters National Fish Barn (Ind. Ichth. Soc, Cibinong, 2021)

10. G.B. da Silva, H.G. Hazin, F.H.V. Hazin, T. Vaske-Jr, J. of App Ichth. 35, 5 (2019) 
11. V.G. Alatorre-Ramirez, F. Galvan-Magaria, Y.E. Torres-Rojas, R.J. Olson, Ocean. Fish. Bull. 115, 2 (2017)

12. E.A. Lewallen, A.J. van Wijnen, C.A. Bonin, N.R. Lovejoy, Mar. Biod. 48, 4 (2018).

13. N.V. Parin, S.V. Bogorodskiy, J. of Ichth. 51, 8 (2011)

14. H.A. Oxenford, R. Manon, W. Hunte, Mar Ecol. Prog. Ser, 11-23 (1995)

15. L.P Fanning, H.A. Oxenford, Ecosystem issues pertaining to the flyingfish fisheries of the Eastern Caribbean. In towards marine ecosystem-based management in the Wider Caribbean. (Amst. Univ. Press, Amsterdam, 2012)

16. P.A. Saveliev, V.E. Kharin, A.A. Balanov, J. of Ichth. 55, 1 (2015)

17. F. Schwartz, J. of the North Carolina Aca. of Sc. 122, 2 (2006)

18. A. Syahailatua, A. Djamali, P. Makatipu, S.A. Ali, J. of Fish. 8, 2 (2006)

19. P. Boli, I. Luhulima, F. Simatauw, S. Leatemia, S. Tabay, D. Parenden, A.S. Ananta, IOP Conf. Ser.: Earth and Env. Sci. 370, 1 (2019)

20. M. Zainuddin, Asian Fish. Sci. 24, 1 (2011)

21. B.M. Rehatta, M.M. Kamal, M. Boer, A. Fahrudin, J.S.R. Ninef, IOP Conf. Ser.: Earth and Envir. Sci. 744, 1 (2021)

22. F. Tuapetel, M.N. Nessa, S.A. Ali, Sudirman, Inter. J. of Sc. and Tech. Res. 4, 3 (2015)

23. G.G. Salamena, J.C. Whinney, S.F. Heron, P.V. Ridd, Estuarine, Coastal and Shelf Sci. 253 (2021)

24. A.S. Silveira Jr, Offshore, inshore, nearshore, remote and distributed. In: building and managing high-performance distributed teams (Apress, Berkeley, 2021)

25. M. Aisawa, Exocoetidae (flyingfishes) ed Nakabo T. Fishes of Japan with pictorial keys to the species (book I, English Ed.) (Tokai Univ. Press, Japan, 2002)

26. N.V. Parin, J. of Ichth. 36, 5 (1996)

27. N.V. Parin, Exocoetidae (flyingfish), ed carpenter and Nien the living marine resources of the western central Pacific (FAO, Rome, 1999)

28. M. Weber, L.F. De Beaufort The fishes of the Indo-Australian Archipelago (E J Brill, Leiden, 1922)

29. Y. Akmal, I. Zulfahmi, M.F. Rahardjo, J. Iktiologi Ind. 18, 3 (2018)

30. J.M. Daane, N. Blum, J. Lanni, H. Boldt, M.K. Iovine, C.W. Higdon, M.P. Harris, bioRxiv (2021)

31. N.V. Parin, I.B. Shakhovskoy, K.E. Bemis, B.B. Collette, Family Exocoetidae. Flyingfishes. In order Beloniformes: Needlefishes, Sauries, Halfbeaks, and Flyingfishes (Yale Univ. Press, New Haven, 2018)

32. I.B. Shakhovskoy, N.V. Parin, J. of Ichth. 53, 2 (2013)

33. H. Park, H. Choi, J. of Exp Bio. 213, 19 (2010)

34. M. Falautano, P. Perzia, L. Castriota, J. of the Mar. Biol. Ass. of the U. King 100, 7 (2020)

35. M. Zainuddin, S. Safruddin, R. Hidayat, A.R.S. Putri, M. Ridwan, IOP Conference Series: Earth and Envir. Sci. 763, 1 (2021)

36. F. Febyanty, A. Syahailatua, Ind. Fish. Res. J 14, 1 (2017)

37. S.A. Ali, IOP Conf. Ser: Earth and Env. Sc. 253, 1 (2019)

38. F. Tuapetel, Ind. J. of Ichth. 22, 2 (2021)

39. S.A. Ali, Flying fish biology (Pustaka Al-Zikra, Makassar, 2019) 
40. Ben Souissi J, Golani D, Mejri H, Capapé C, J. of Fish Bio. 67, 4 (2005)

41. R. Olson, L. Duffy, P. Kuhnert, F. Galván-Magaña, N. Bocanegra-Castillo, V. AlatorreRamírez, Mar. Eco. Pro. S 497, 157-178 (2014)

42. F. Tuapetel, M.N. Nessa, S.A. Ali, Sudirman, B.G. Hutubessy, J.W. Mosse, IOP Conf. Series: Earth and Env. S 89, 1 (2017)

43. L. Wu, X. Liu, P. Fu, L. Xu, X. Wang, Y. Sun, Y. Li, Mar. Eco. Prog. S 585, 175-183 (2017)

44. S. Muhammad, A. Mallawa, M. Zainuddin, Science and Technology J. of Fish. Res. Utiliz. 5, 9 (2018)

45. T.S. Harahap, A. Djamali, Indo. J. of Ichth. 5, 2 (2005)

46. F. Ferdiansyah, A. Syahailatua, BAWAL Widya Capt. Fish. Res. 3, 3 (2017)

47. S.A. Ali, M.N. Nessa, M.I. Djawad, S.B.A. Omar, A. Djamali, Torani J. of Mar. Sc. and Fish. 6, 15 (2005)

48. S.A. Ali, M.N. Nessa, M.I Djawad, S.B.A. Omar, Torani 14, 3 (2004)

49. A.R. Syam, T. Zubaidi, I.N. Edrus, Ind. J. of Fish. Res. 10, 4 (2017)

50. V.J. Pical, L.M. Soukotta, M. Sangaji, TECHNO-FISH. 3, 1 (2019)

51. M. Palo, N. Najamuddin, Agrokompleks 16, 1 (2017)

52. M. Palo, M. Zainuddin, S.A. Farhum, Aquaculture, Aquarium, Cons. \& Leg. 124, 1404-1412 (2019)

53. F. Tuapetel, Warta Iktiologi 4, 3 (2020)

54. F. Tuapetel, Management of flying fish resources in Maluku waters in Rahardjo and Tuapetel. Management and conservation of pelagic fish resources in Maluku waters National Fish Barn. Ind (Ichth. Soc, Cibinong, 2021) 